\title{
THE COMBINATION FAMILY BASKET
}

\section{A COMMUTER'S PLAN FOR DIRECT MARKETING}

\author{
By Harry Sprackland, \\ Barrington, N. J.
}

Working in the city and living on a one-acre farm in the country where I have "the time of my life" raising vegetables, chickens and small fruits with which I abundantly supply my family of eight, I have in a measure solved the problem of the high cost of living. Incidentally I have created an outlook for my children that more than discounts the artificialities of city life.

I found that, like the average farmer, I was growing more vegetables than I could use, and that the surplus was being wasted. I decided to try to sell some. The grocer from the nearby town agreed to take some lettuce and romain salad at 36 cents per dozen and some radishes at 30 cents per dozen bunches. I observed that the lettuce and romain salad retailed at from 8 cents to 12 cents per head and the radishes at 5 cents per bunch. I felt that I wanted more of that profit. However, I had neither the time nor facilities to retail what I had; yet the desire to collect some of that profit almost consumed me, for I was intensely interested in farming and had planned to go into it as soon as I could.

One morning in August I gathered from my garden a quarter of a peck of string beans, two heads of cabbage, two bunches of beets, one cauliflower, two fordhock squash (or English vegetable marrow, as it is called), one bunch of Swiss chard, a vegetable whose green tops are destined to take the place of spinach and whose large while stalks may be cooked the same as asparagus, and a quarter of a peck of tomatoes; also a bunch of potherbs containing twenty sprays of parsley, ten sprays of celery, two carrots, two leeks, two roots of oyster plant, six pieces of okra, three green peppers, some thyme and summer savory. All this I placed in a farmer's half bushel basket. It contained a vegetable for every day in the week, and a potherb that is of tremendous value to the housekeeper who knows. I delivered the basket, neatly covered, to the home of a friend in the city and explained to his wife that I would have brought twice the amount or 
more were it not for the distance and weight. I asked her to look over the vegetables and tell me what she would have to pay for them at the corner grocery store as I was studying a business proposition in connection with them. Her exclamations of delight as she took one thing after another from the basket- "Just look how fresh!" "Aren't they perfectly lovely!" "I could never buy anything like these in the city." "They are so fresh looking and so bright and clean"-were all glorious music in my ears, and I felt that I had "struck oil." After taking stock, like the keen housekeeper I knew her to be, she daclared that, were it possible for her to buy such things, the cost would be from $\varepsilon 5$ cents to $\$ 1$ a basket. I asked for her candid opinion as to whether the people in such a neighborhood as hers would purchase weekly, from the farmer's wagon, baskets like this one at 60 cents each. She expressed her willingness to take one every week and felt sure I would have no trouble in selling all I could grow. Needless to say, I felt elated.

I delivered many of these baskets in the city and found that the housekeepers readily recognized the benefit they derived from purchasing in this way. Just at this time I saw, through the agency of the parcel post, the possibility of a business direct from the farm; for the delivery was solved if I could put up a basket to meet the weight requirements. With this in view, I placed in a peach box or carrier, one quarter of a peck of tomatoes, one quarter of a peck of lima beans, fresh hulled, and the "potherb" I have described above. I felt that a small family would appreciate that at 25 cents at the nearby town, and, with a little explanation of the virtues of the freshness of the vegetables and the multitude of uses for which the "potherb" would be available, such as a pot roast, a soup or a stew, besides garnishing for salad, etc., I had little trouble in selling the same on my way to the city. I made up many of these baskets and they found a ready sale.

Strange, yet true, right here in the country where these things grow, they are hauled to the city, and then hauled back again by the grocers and sold to the neighbors of the farmers who grew them. Here is a field which to me offers limitless possibilities. In this same country place I have a friend who is somewhat interested in farm life, and, being a chef in one of the leading clubs of the city, he is a past master in the art of preparing food as a business. We have threshed out many things together besides the value of vegetables 
fresh from the farm. We have put up in glasses for our own use vegetables and fruits the equal of which no money can buy in the ordinary channels of trade. The commercial spirit reached us on these things and we laid plans for their delivery to the waiting consumer.

In November last I took stock of what my wife had that summer preserved and canned for our winter use. I found: 91 half-pint glasses of strawberry jam, 48 pint glasses of red currant and raspberry jam; 60 pint glasses of gooseberry jam, 100 pint glasses of grape jelly; 80 half-pint glasses of grape jelly; 80 pint glasses of grape jam; 50 quart jars of Keiffer pears; 4 quarts of wild cherry syrup; 70 quart jars of string beans; 60 quart jars of tomatoes; 30 quart jars of tomatoes and corn, 20 quart jars of tomatoes and okra, 50 quart jars of gumbo creole, 10 quart jars of pickled beets, 20 quart jars of green pickled tomatoes, 24 quart jars of tomato chutney, 5 gallons of sour crout, 5 gallons of red pickled cabbage. Some of the garden stuff of the summer of 1912 is as follows: 1200 heads lettuce and romain salads; radishes; peas; rhubarb, 10 clumps; cabbage, 200 heads; cauliflower, 100 heads; string beans early and late; lima beans; kohl rabj; Swiss chard early and late; spinach; early potatoes; okra; parsley; leeks; celery; oyster plant; green peppers; thyme; beets; carrots; estrajon; corn; 1,000 heads curled endive salad; mint.

If all these things were charged up at current prices, they would take care of the interest on the home up to $\$ 2,000$. And that, to the man who has little but spare time to invest, spells independence for old age. Judging this by the standard of dollars and cents, it is a great success, yet that is outweighed as an asset to the family's health through our unlimited quantities of food to say nothing of the ennobling influence of such a life and teaching upon our children.

The strawberries which my wife preserved were purchased from a near-by farm at 4 cents per quart, the Keiffer pears at 15 cents per basket, the wild cherries were picked on the roadside. The other things and more were produced on less than one-half an acre, the remaining land being occupied by the house, lawns, flower beds, chicken house, runs, fruit trees, and grape vines, planted three years ago, some of which are beginning to bear. Experience has taught me that better results could be accomplished by confining the country home to one-half an acre, for intensive methods give larger returns with much less labor. 
Further study of this fascinating problem of the distribution of farm products led me to take up the subject with the neighboring farmers and to each of them I suggested the possibilities of the combination family basket. Admitting the logic of my arguments as to its possibilities, I was forced to realize in each case that the change from their present methods was too much for them to attempt even as an experiment. This I attribute to their environment and lack of contact with new things. The weight of the family basket, packed as described, varies from twenty-five to thirty pounds. In studying how their weight might be reduced that more might be hauled to town, I made up a smaller basket to suit the requirements of a small family. After experimenting, I found the ideal basket to be eighteen inches long, twelve inches wide, nine inches deep, without a handle, costing $\$ 3$ to $\$ 4$ per hundred. In this basket I placed one small head of cabbage, one quart of string beans, one quart of lima beans, one quart of tomatoes, and one "potherb," containing eight different vegetables and seasoning herbs and six green peppers. This basket, lined and covered with oiled paper, wrapped with stout paper, tied with string, which serves also for $a$ handle, weighed twelve and one-half pounds and solved the weight problem.

I believe that were this hamper idea adopted by commuting farmers and by truck gardeners, it would add profit to their pleasure and prove a stimulus to the back-to-the-land movement. The farmer would see its success and during its growth would have time to adjust his business to meet the conditions of the new kind of farm. The high cost of living would also be reduced, for through the medium of the basket, chickens, ducks, butter, eggs, jams, jellies, and in fact the whole product of the farm, could be delivered to the consumer. 